\title{
Hb A1c Separation by High Performance Liquid Chromatography in Hemoglobinopathies
}

\author{
Vani Chandrashekar \\ Department of Hematology, Apollo Hospitals, No. 21, Off Greams Road, Greams Lane, Chennai 600006, India \\ Correspondence should be addressed to Vani Chandrashekar; drvani001@gmail.com
}

Received 2 December 2015; Revised 16 January 2016; Accepted 24 January 2016

Academic Editor: Ali S. Calikoglu

Copyright ( 2016 Vani Chandrashekar. This is an open access article distributed under the Creative Commons Attribution License, which permits unrestricted use, distribution, and reproduction in any medium, provided the original work is properly cited.

\begin{abstract}
$\mathrm{Hb}$ Alc measurement is subject to interference by hemoglobin traits and this is dependent on the method used for determination. In this paper we studied the difference between Hb Alc measured by HPLC in hemoglobin traits and normal chromatograms. We also studied the correlation of $\mathrm{Hb} \mathrm{Alc}$ with age. Hemoglobin analysis was carried out by high performance liquid chromatography. Spearman's rank correlation was used to study correlation between Alc levels and age. Mann-Whitney $U$ test was used to study the difference in $\mathrm{Hb}$ Alc between patients with normal hemoglobin and hemoglobin traits. A total of 431 patients were studied. There was positive correlation with age in patients with normal chromatograms only. No correlation was seen in $\mathrm{Hb} \mathrm{E}$ trait or beta thalassemia trait. No significant difference in $\mathrm{Hb}$ Alc of patients with normal chromatograms and patients with hemoglobin traits was seen. There is no interference by abnormal hemoglobin in the detection of Alc by high performance liquid chromatography. This method cannot be used for detection of Alc in compound heterozygous and homozygous disorders.
\end{abstract}

\section{Introduction}

$\mathrm{Hb}$ Alc represents the fraction of hemoglobin bound to glucose [1]. Some of the methods for measuring Alc are boronate affinity, electrophoresis, cation exchange chromatography, and immunoassay [2]. Hemoglobinopathies can affect Alc measurement in various ways-by altering glycation of hemoglobin, by causing hemolysis thus reducing glycation time, and also by producing a peak in chromatograms rendering interpretation difficult [3]. The effect of hemoglobinopathies on glycated hemoglobin is method dependent [4]. It was seen that low or high value for $\mathrm{Hb} \mathrm{Alc}$ was reported in the presence of hemoglobinopathies while using high performance liquid chromatography, immunoassay, and immunoagglutination methods [4]. It was seen that boronate affinity method showed acceptable values in the presence of hemoglobinopathies [4]. Discrepancies between home blood glucose monitoring and Alc measurements have been reported to be around $20.3 \%$ and these discrepancies have been seen in patients with hemoglobinopathies [5]. Presence of $\mathrm{Hb} \mathrm{S}$ or $\mathrm{Hb} \mathrm{C}$ has been reported to affect $\mathrm{Alc}$ measurements $[2,6-10]$. In another study evaluating 14 methods for $\mathrm{Hb} \mathrm{Alc}$ measurement, there was no interference by $\mathrm{Hb} \mathrm{C}$ and $\mathrm{Hb} \mathrm{S}$ on $\mathrm{Hb}$ Alc measurement by ion exchange chromatography [11]. With $\mathrm{Hb} \mathrm{D}$ and $\mathrm{Hb}$ E traits certain ion exchange chromatography methods were found to be acceptable with no interference on Alc measurement [12].

In this study we studied the difference in levels of $\mathrm{Hb}$ Alc in patients with and without hemoglobinopathies. We also studied the chromatograms for possible interference by abnormal hemoglobin.

\section{Materials and Methods}

EDTA anticoagulated blood samples were collected from patients after informed consent for complete blood counts and hemoglobin analysis. Patients with history of recent blood transfusion within the preceding three months were not included in the study. For complete blood counts samples were analyzed within four hours of collection in LH 780 analyzer (Beckman Coulter). High performance liquid exchange chromatography (HPLC) using Hemoglobin A1c/A2/F BIORAD D-10 dual program on D-10 analyzer (Bio-Rad) separated the hemoglobin fractions. The samples were directly loaded into the instrument after which they were automatically diluted and injected into the analytical cartridge. Then 


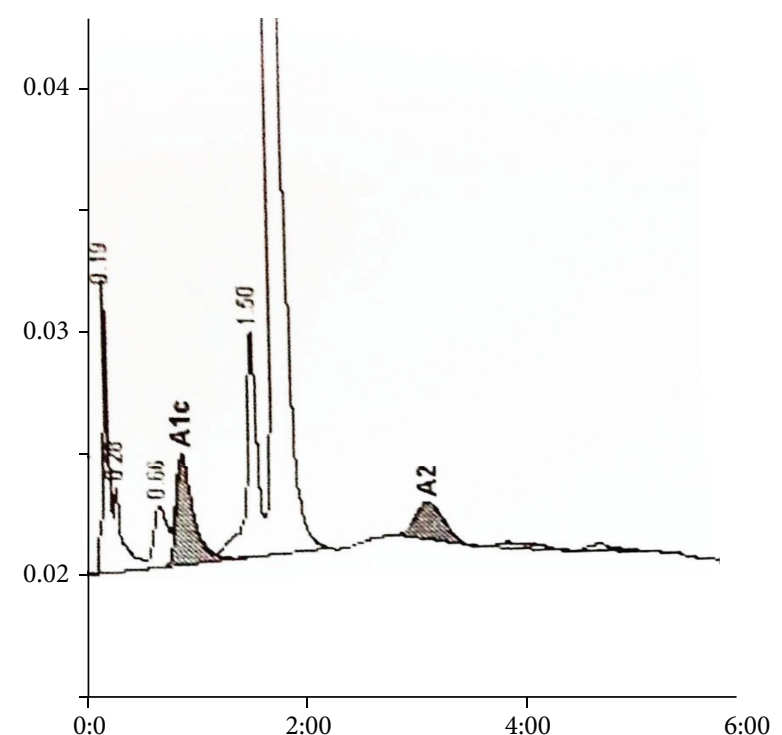

FIGURE 1: Alc of $4.7 \%$ at retention time of 0.87 minutes in a normal chromatogram.

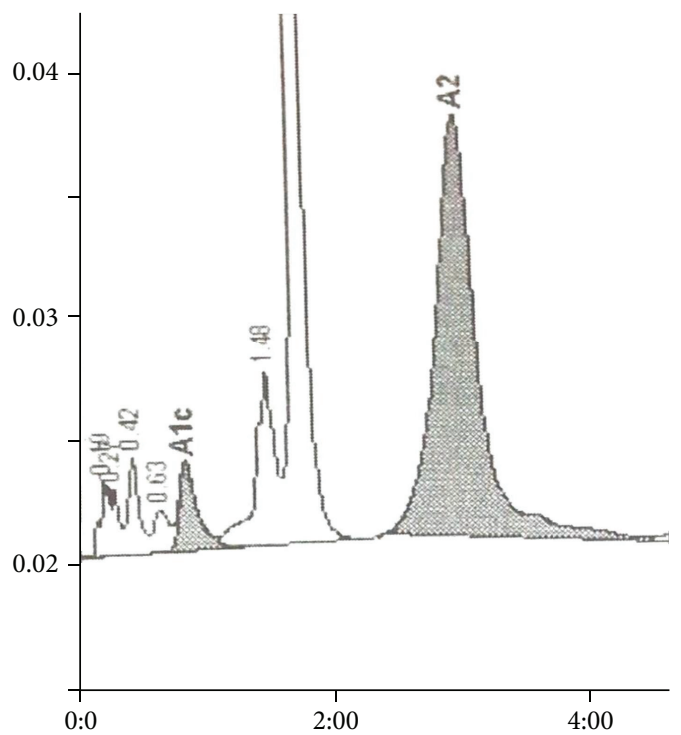

FIGURE 2: Alc of $4.8 \%$ at retention time of 0.83 minutes in $\mathrm{Hb} \mathrm{E}$ trait.

a programmed buffer gradient of increasing ionic strength was delivered to the cartridge. The hemoglobin separated based on its ionic interactions with the cartridge. The eluted hemoglobin flows through a flow cell where its absorbance at $415 \mathrm{~nm}$ was recorded. The D-10 software performs reduction of the raw data and a chromatogram is generated which will have the peaks in the following order: $\mathrm{Hb} \mathrm{Ala}, \mathrm{Hb} \mathrm{Alb}, \mathrm{Hb}$ F, LAlc/CHb-1, Hb Alc, $\mathrm{Hb} \mathrm{P} 3, \mathrm{Hb} \mathrm{A} 0$, and $\mathrm{Hb} \mathrm{A} 2$. There are two levels of calibration for $\mathrm{Hb}$ F, $\mathrm{Hb} \mathrm{Alc}$, and $\mathrm{Hb} \mathrm{A} 2 \mathrm{Hb}$ Alc is calculated after subtracting the labile and carbamylated portion. The chromatograms were analyzed for presence of $\mathrm{Hb}$ Alc peak and variant peaks (Figures 1 and 2). The variant hemoglobin was identified by its retention times and comparing it with manufacturer assigned retention times. If the total chromatogram area exceeded 4 million $\mu$ volts or was less than 1 million $\mu$ volts the results were considered inaccurate. Variant hemoglobin ( $\mathrm{Hb}) \mathrm{D}, \mathrm{Hb} \mathrm{E}$, and $\mathrm{Hb} \mathrm{S}$ separated into windows. $\mathrm{Hb} \mathrm{E}$ trait separated as $\mathrm{Hb} \mathrm{A} 2$ (30-39\%) whereas $\mathrm{Hb} \mathrm{S}$ and $\mathrm{Hb} \mathrm{D}$ separated into a window beyond $\mathrm{Hb} \mathrm{A} 2$. Beta thalassemia traits were identified by elevated $\mathrm{Hb}$ A2 (but less than 9\%) and minimal or no elevation of $\mathrm{Hb} F$. Beta thalassemia major was identified by high $\mathrm{Hb} F$ levels whereas homozygous $\mathrm{E}$ had $\mathrm{Hb} \mathrm{E}$ levels beyond $85 \%$ and minimal elevation of $\mathrm{Hb} \mathrm{F}$. Hb Alc was expressed as percentage of the total hemoglobin. The Alc levels were used to subdivide the patients into normal and diabetic using the classification of the American Diabetes Association (less than 5.7\% as normal and $6.5 \%$ and above as diabetes).

2.1. Statistical Methods. Data were entered into excel worksheets. Normality was determined by normal probability plots. Since $\mathrm{Hb} \mathrm{Alc}$ showed a distribution which was not normal, nonparametric tests-Spearman's ranked correlation (Vassar stats) and Mann-Whitney $U$ test-were used. Spearman's ranked correlation was used to study the correlation and level of significance between age and $\mathrm{Hb}$ Alc measurements in normal chromatograms as well as traits. MannWhitney $U$ test (Vassar stats) was conducted to test the null hypothesis that $\mathrm{Hb} \mathrm{Alc}$ levels between the two groupsnormal hemoglobin and hemoglobin traits-are similar. Significant $p$ level was considered to be less than 0.05 .

2.2. Observations. A total of 431 chromatograms and complete blood counts were analyzed. Among these, 71 patients with diabetes ( $\mathrm{Hb} \mathrm{Alc}$ of 6.5 and more) and low $\mathrm{Hb}$ Alc (less than $4 \%$ ) were excluded. From the remaining 360 patients, normal chromatogram was seen in 186 . There were 122 females and 64 males. Median age was 32 years. Youngest patient was 17 years old whereas the oldest was 87 years old. Median hemoglobin was $105 \mathrm{gm} / \mathrm{L}$. Hemoglobin varied from 33 to $162 \mathrm{gm} / \mathrm{L}$. Hb Alc peaks were visualised in all chromatograms. Median $\mathrm{Hb}$ Alc was $5.3 \%$ with a range from 4 to $6.4 \%$. Median $\mathrm{Hb} \mathrm{A}$ was $85.8 \%$ with a range from 79.5 to $89.2 \%$.

A total of 119 patients had hemoglobinopathy or beta thalassemia trait which included 63 with beta thalassemia trait, 48 with $\mathrm{Hb}$ E trait, five with $\mathrm{Hb} \mathrm{S}$ trait, and three with $\mathrm{Hb} \mathrm{D}$ trait. Patients with sickle cell trait and $\mathrm{Hb} \mathrm{D}$ trait were excluded as they were few in number. Among patients with beta thalassemia trait, there were 36 males and 27 females. The median age was 32 years. Age varied from one to 70 years. Median hemoglobin was $109 \mathrm{gm} / \mathrm{L}$. Hemoglobin varied from 74 to $149 \mathrm{gm} / \mathrm{L}$. Hb Alc peaks were visualised in all chromatograms. Median $\mathrm{Hb}$ Alc was $5.4 \%$ with a range from 4.2 to $6.3 \%$. Median $\mathrm{Hb} \mathrm{A}$ was $82.4 \%$ with a range from 74.8 to $85.2 \%$. Median $\mathrm{Hb} \mathrm{A} 2$ was $5.3 \%$ with a range from 3.6 to $7 \%$. Among patients with $\mathrm{Hb} \mathrm{E}$ trait, there were 24 males and 24 females. The median age was 33.5 years. Age varied from one to 72 years. Median hemoglobin was $106 \mathrm{gm} / \mathrm{L}$. Hemoglobin varied from 57 to $154 \mathrm{gm} / \mathrm{L}$. Hb Alc peaks were visualised in all chromatograms. Median $\mathrm{Hb}$ Alc was $5.2 \%$ with a range from 4.4 to $6.2 \%$. Median $\mathrm{Hb} \mathrm{A}$ was $61.0 \%$ with a range from 
TABLE 1: Median of various hemoglobin fractions separated by chromatography.

\begin{tabular}{lcccccc}
\hline Chromatogram & Numbers & Age in years (median) & Hb Alc\% & Hb A\% & Abnormal Hb/elevated Hb A2\% \\
\hline Normal & 186 & 32 & 5.3 & 85.8 & Nil \\
\hline Beta thalassemia trait & 63 & 32 & 5.4 & 82.4 & 5.3 \\
\hline Hb E trait & 48 & 33.5 & 5.2 & 61.0 & 27.3 \\
\hline
\end{tabular}

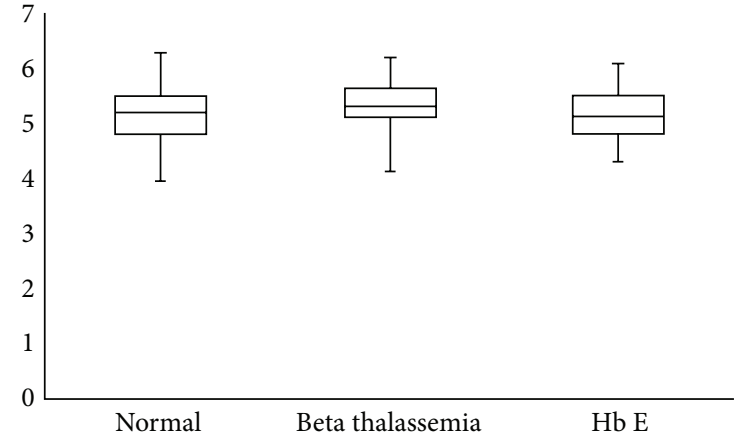

FIgURE 3: Box plot showing quartiles 1, 2, and 3 for $\mathrm{Hb}$ Alc in normal chromatograms, beta thalassemia trait, and $\mathrm{Hb} \mathrm{E}$ trait.

56.8 to $69.0 \%$. Median $\mathrm{Hb} \mathrm{E}+\mathrm{Hb} \mathrm{A} 2$ was $27.3 \%$ with a range from 20.4 to $30.2 \%$.

Compound heterozygous/homozygous hemoglobinopathies were seen in 55 patients. Homozygous $\mathrm{Hb} \mathrm{E}$ was seen in 37 patients, beta thalassemia major was seen in eight, compound heterozygous $\mathrm{Hb}$ E/beta thalassemia was seen in five, homozygous sickle was seen in three, $\mathrm{Hb} \mathrm{H}$ was seen in one, and compound heterozygous $\mathrm{Hb}$ S/beta thalassemia was seen in one patient. There were 28 males and 27 females.

2.3. Spearman's Ranked Correlation. Age had a significant positive correlation with $\mathrm{Hb}$ Alc in normal individuals, $r_{s}=$ $0.39, p<0.000001(\mathrm{df}=184, n=186)$. No significant correlation was seen in beta thalassemia traits, $r_{s}=0.24, p=0.05$ ( $\mathrm{df}=61, n=63$ ). Age had no significant relationship with $\mathrm{Hb}$ Alc in Hb E trait, $r_{s}=0.06, p=0.6(\mathrm{df}=46, n=48)$.

2.4. Mann-Whitney $U$ Test. Hb Alc from normal patients does not differ significantly from patients with traits, $z=$ $-0.9, p=0.368$. Patients with normal chromatograms had a rank of 145.5 whereas patients with traits had a rank of 154.8.

$\mathrm{Hb} \mathrm{Alc}$ from normal patients does not differ significantly from patients with $\mathrm{Hb} \mathrm{E}$ trait, $z=0.6, p=0.54$. Patients with normal hemoglobin had a rank of 118.9 whereas patients with $\mathrm{Hb} \mathrm{E}$ trait had a rank of 112.3 . Hb Alc from normal patients does not differ significantly from patients with beta thalassemia trait, $z=-1.82, p=0.06$. Patients with normal hemoglobin had a rank of 120.2 whereas patients with beta thalassemia trait had a rank of 139.3.

Differences between patients with normal hemoglobin and traits are tabulated in Table 1.

Figure 3 is a box plot summary of $\mathrm{Hb}$ Alc distribution. Note that the medians are 5.3, 5.4, and 5.2 for normal hemoglobin, beta thalassemia trait, and $\mathrm{Hb} \mathrm{E}$ trait.

\section{Discussion}

Interference with $\mathrm{Hb} \mathrm{Alc}$ measurement by hemoglobin traits has been described previously [2, 5-10]. A detailed list of interference by hemoglobin variants as well as method used has been listed (http://www.ngsp.org/). In this study, we did not find difference between $\mathrm{Hb}$ Alc levels in patients with hemoglobin traits and normal hemoglobin. This implies that $\mathrm{Hb} \mathrm{E}$ and beta thalassemia trait do not interfere with Alc measurements by HPLC on D-10 analyzer using the Hemoglobin A1c/A2/F BIO-RAD D-10 dual program. Patients with normal hemoglobin showed significant positive correlation between age and $\mathrm{Hb}$ Alc levels. This could be due to the number of patients with $\mathrm{Hb} \mathrm{E}$ trait (48) and beta thalassemia trait (63) compared to normal hemoglobin (186) in this study. In order to investigate further we conducted a Mann-Whitney $U$ test between Alc levels from patients with normal hemoglobin and those with $\mathrm{Hb} \mathrm{E}$ trait and beta thalassemia trait. $\mathrm{Hb}$ Alc results for patients with $\mathrm{HbE}$ or beta thalassemia trait are not significantly different from those of normal subjects. In conclusion, $\mathrm{Hb}$ Alc measurement by HPLC using the extended program of D-10 analyzer is reliable in hemoglobin traits studied. However, in compound heterozygous and homozygous states, other methods for detection of $\mathrm{Hb} \mathrm{Alc}$ have to be used as there is no $\mathrm{Hb} \mathrm{Alc}$ peak due to absence of $\mathrm{Hb} \mathrm{A}$. According to the manufacturer $\mathrm{Hb} \mathrm{C}, \mathrm{Hb} \mathrm{D}, \mathrm{Hb} \mathrm{E}$ and $\mathrm{Hb} \mathrm{S}$ trait do not interfere with $\mathrm{Hb}$ Alc levels and value obtained by the D-10 dual extended program is similar to the boronate affinity method. Hb Alc level from patients with normal hemoglobin is not different from patients with hemoglobin traits. We also found that frequency of patients with diabetes did not differ in patients with hemoglobinopathy/thalassemia traits when compared to the normal population (10.5 and 9.8, resp.).

\section{Conflict of Interests}

The author has no conflict of interests to declare.

\section{Acknowledgments}

The author is grateful to Mr. Madhusudana Rao and Kavitha $\mathrm{M}$ for their technical help.

\section{References}

[1] H. A. Tran, D. Silva, and N. Petrovsky, "Case study: potential pitfalls of using hemoglobin Alc as the sole measure of glycemic control," Clinical Diabetes, vol. 22, no. 3, pp. 141-143, 2004.

[2] L. Bry, P. C. Chen, and D. B. Sacks, "Effects of hemoglobin variants and chemically modified derivatives on assays for 
glycohemoglobin," Clinical Chemistry, vol. 47, no. 2, pp. 153-163, 2001.

[3] P. Gillery, G. Hue, M. Bordas-Fonfrede et al., "Hemoglobin A1C determination and hemoglobinopathies: problems and strategies," Annales de Biologie Clinique, vol. 58, no. 4, pp. 425429, 2000.

[4] W. J. Schnedl, R. Krause, G. Halwachs-Baumann, M. Trinker, R. W. Lipp, and G. J. Krejs, "Evaluation of HbAlc determination methods in patients with hemoglobinopathies," Diabetes Care, vol. 23, no. 3, pp. 339-344, 2000.

[5] J. E. Gunton and A. McElduff, "Hemoglobinopathies and $\mathrm{HbA}(1 \mathrm{c})$ measurement," Diabetes Care, vol. 23, no. 8, pp. 1197$1198,2000$.

[6] W. J. Schnedl, A. Liebminger, R. E. Roller, R. W. Lipp, and G. J. Krejs, "Hemoglobin variants and determination of glycated hemoglobin (HbAlc)," Diabetes/Metabolism Research and Reviews, vol. 17, no. 2, pp. 94-98, 2001.

[7] C. W. Weykamp, W. V. Martina, F. P. L. van der Dijs, T. J. Penders, W. van der Slik, and F. A. J. Muskiet, "Hemoglobins S and C: reference values for glycohemoglobin in heterozygous, doubleheterozygous and homozygous subjects, as established by 13 methods," Clinica Chimica Acta, vol. 231, no. 2, pp. 161-171, 1994.

[8] W. L. Roberts, J. M. Chiasera, and K. M. Ward-Cook, "Glycohemoglobin results in samples with hemoglobin C or S trait: a comparison of four test systems," Clinical Chemistry, vol. 45, no. 6, pp. 906-909, 1999.

[9] E. L. Frank, L. Moulton, R. R. Little, H.-M. Wiedmeyer, C. Rohlfing, and W. L. Roberts, "Effects of hemoglobin C and S traits on seven glycohemoglobin methods," Clinical Chemistry, vol. 46, no. 6, pp. 864-867, 2000.

[10] W. L. Roberts, B. K. De, D. Brown et al., "Effects of hemoglobin C and S traits on eight glycohemoglobin methods," Clinical Chemistry, vol. 48, no. 2, pp. 383-385, 2002.

[11] S. K. Mongia, R. R. Little, C. L. Rohlfing et al., "Effects of hemoglobin $\mathrm{C}$ and $\mathrm{S}$ traits on the results of 14 commercial glycated hemoglobin assays," American Journal of Clinical Pathology, vol. 130, no. 1, pp. 136-140, 2008.

[12] R. R. Little, C. L. Rohlfing, S. Hanson et al., "Effects of hemoglobin $(\mathrm{Hb}) \mathrm{E}$ and $\mathrm{HbD}$ traits on measurements of glycated $\mathrm{Hb}$ $\left(\mathrm{HbA}_{1 \mathrm{c}}\right)$ by 23 methods," Clinical Chemistry, vol. 54, no. 8, pp. 1277-1282, 2008. 


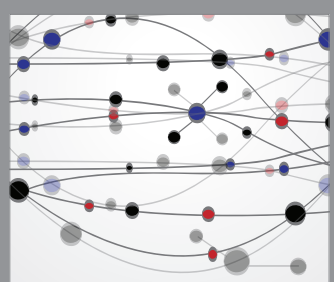

The Scientific World Journal
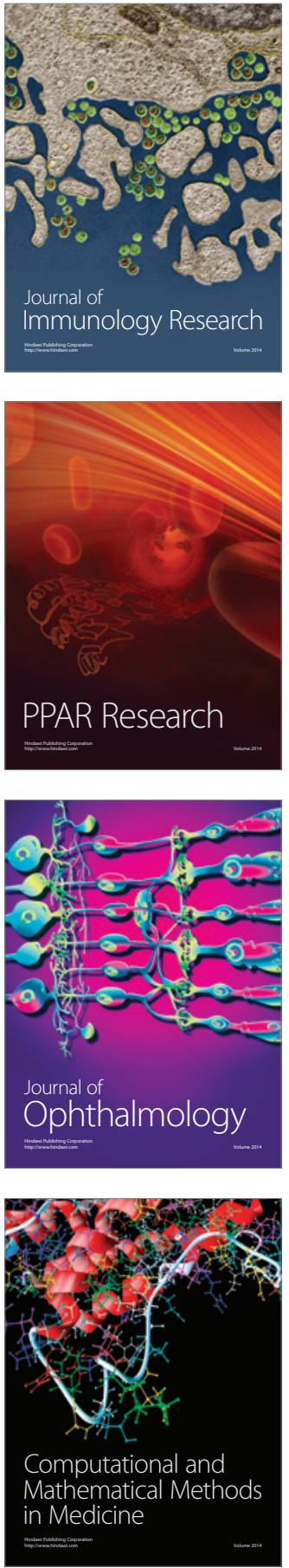

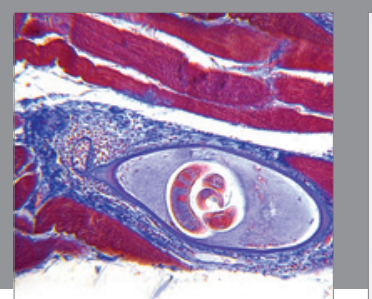

Gastroenterology Research and Practice

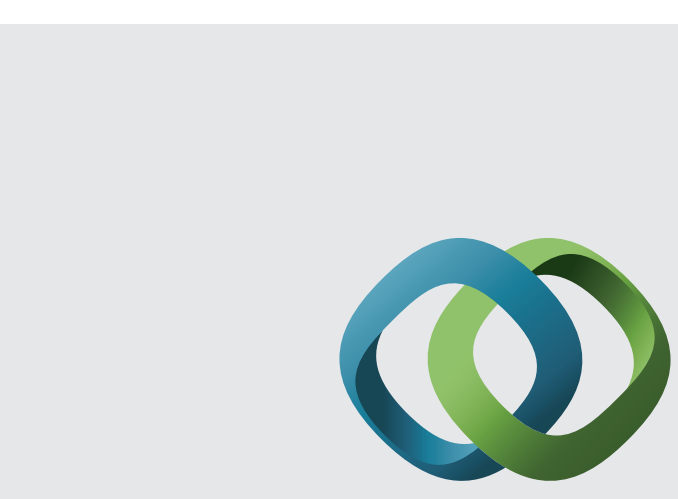

\section{Hindawi}

Submit your manuscripts at

http://www.hindawi.com
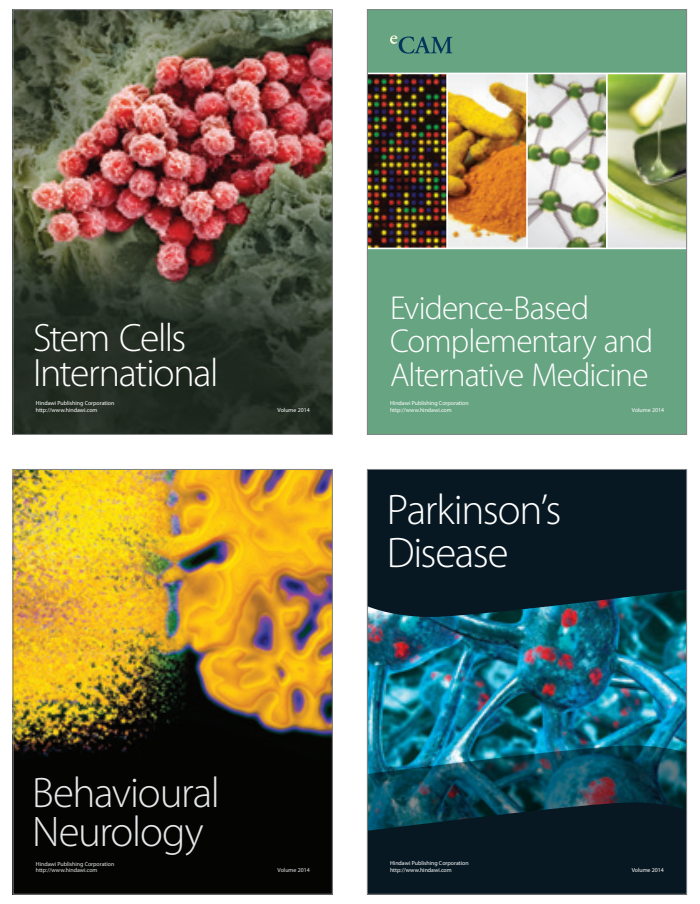
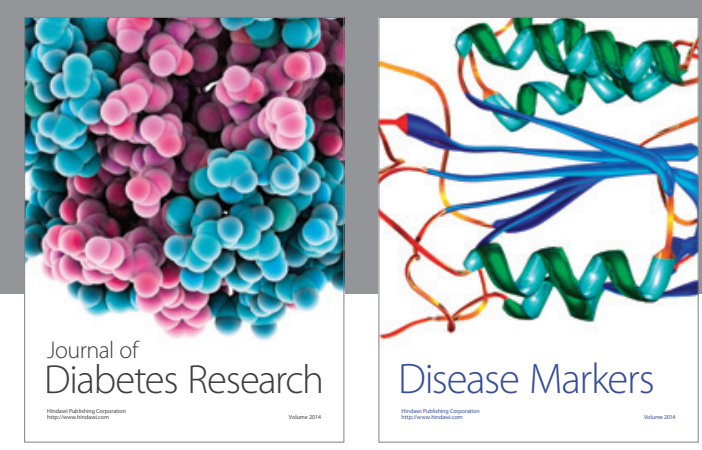

Disease Markers
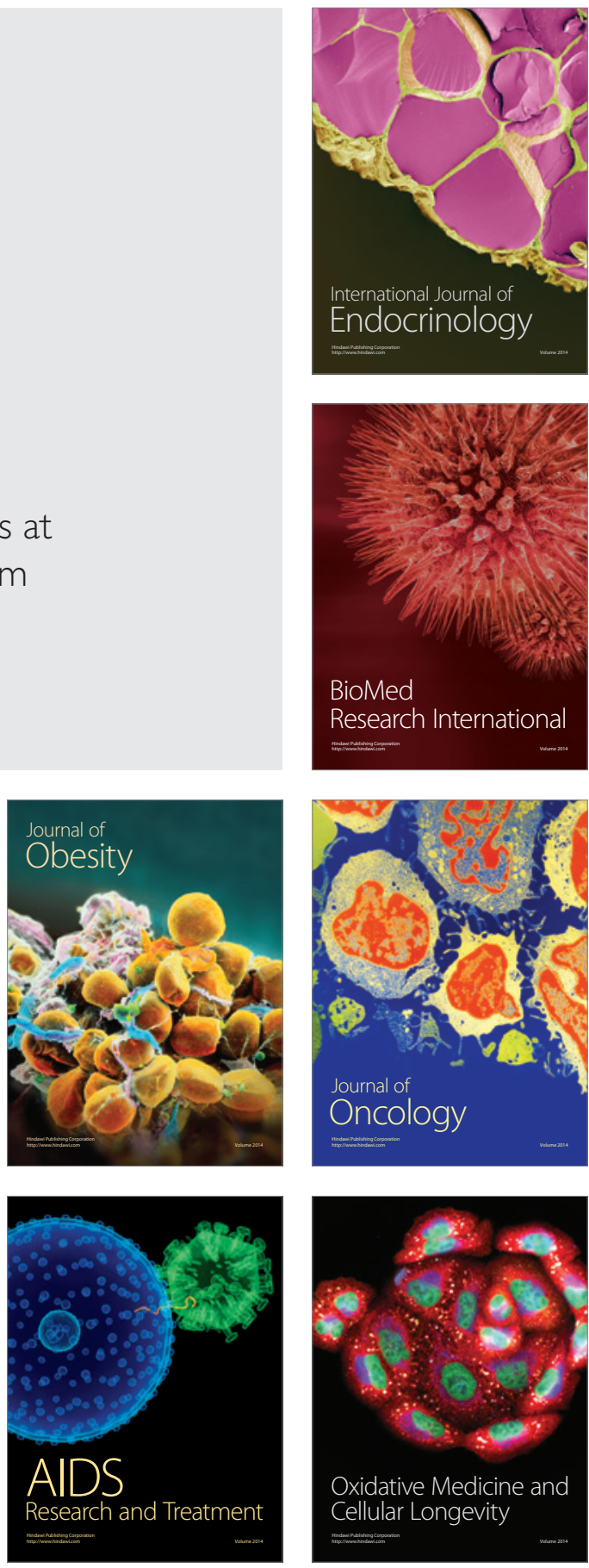